\title{
RESPONSE OF BIOCHEMICAL CHARACTERISTICS AND GRAIN YIELD OF CANOLA (BRASSICA NAPUS L.) TO BIOFERTILIZERS
}

\section{Zeinab Amanolahi Baharvand, Morteza Siavoshi ${ }^{*}$, Yosoof Niknezhad, Hormoz Fallah and Masoud RafieE ${ }^{2}$}

\author{
Department of Agricultural, International Ayat-o-Allah Amoli Branch, \\ Islamic Azad University, Iran
}

Keywords: Azotobacter, Grain yield, Mycorrhiza, Oil yield, Rapeseed

\begin{abstract}
Effects of Mycorrhiza and Azotobacter biofertilizers on the biochemical properties and grain yield of rapeseed cultivars were investigated in a randomized complete block design with four replications in two years 2016 and 2017 in Khorramabad, Lorestan province, Iran. Biofertilizer factors included application of Mycorrhiza, Azotobacter, Mycorrhiza and Azotobacter combination and non-application of biofertilizer (control) and cultivar factors included Gabriella, Neptune, Expower and Okapi. According to interaction effect of biofertilizers $\times$ cultivar, results showed that the highest seed and oil yields were obtained with the application of Mycorrhiza and Azotobacter combination in case of Gabriella (4918.6 and $1165.2 \mathrm{~kg} / \mathrm{ha}$, respectively) and the least was found with non-application of biofertilizers in case of Expower (3350.4 and $731.3 \mathrm{~kg} / \mathrm{ha}$, respectively). Biochemical parameters like shoot proline, protein, peroxidase, catalase, Chlorophyll $\mathrm{a}$ and $\mathrm{b}$ content of canola were also significantly affected by biofertilizer, cultivar and due to interaction of biofertilizer and cultivar. Therefore, application of Mycorrhiza and Azotobacter combination in case of Gabriella is recommended for Khorramabad and similar regions.
\end{abstract}

\section{Introduction}

One of the world's major oilseed crops canola (Brassica napus L.) is the most important source of edible oil (Zhou 1994). The nutritional value and importance of oilseeds have a special place in the supply of human and animal calories among agricultural products. Increasing demand for edible oil in world markets and the pressure from the cost of buying and importing oil are among the factors that determine the importance of developing oilseed crops and expanding scientific research programs (Nematollahi and Saeidi 2011). Rapeseed is one of the most important annual oilseed plants that have an important role in providing energy and food security worldwide (Ahmad et al. 2005). It is also one of the most important oilseeds after soybean because of its adaptation to wide climatic conditions. Rapeseed crop development is a promising source of supply to meet the country's oil needs (Ahmad et al. 2005, Seyed Sharifi 2007). Due to climate change in recent years, rapeseed, like other irrigated crops, faces drought stress and damage. In order to adapt the plant to arid climatic conditions, morphological, physiological changes and accumulation of new metabolites along with structural changes increase plant yield and yield under stressful conditions. Therefore, a better understanding of the relationships between plant environment and genotype and investigating the physiological, biochemical and molecular properties of the plant under adverse environmental conditions, especially drought stress, will lead to a better understanding of plant adaptation and events involved in drought tolerance mechanisms (Smirnoff 1993). Increased concentrations of plant hormones and chlorophyll content are the most important symbiotic roles of biological fertilizers such as Mycorrhiza and Azotobacter in the agricultural system (Barea et al.1997).

*Author for correspondence: <Morteza_siavoshi@yahoo.com>. ${ }^{1}$ Department of Agricultural Science, Payame Noor University, Iran. ${ }^{2}$ Lorestan Agricultural and Natural Resources Research and Education Center, Iran. 


\section{Materials and Methods}

This study was conducted in moderate region of Khorramabad. It has latitude of $33^{\circ} 29^{\prime}$ north, longitude $48^{\circ} 18^{\prime}$ east, altitude 1195 meters above sea level and average annual precipitation based on 35 year-old meteorological statistics $516 \mathrm{~mm}$ and average long-term temperature $16.2^{\circ} \mathrm{C}$. The meteorological data are shown in Fig. 1 for the 2016 and 2017 including actual maximum temperatures (L1 act Max), maximum mean (L1 Max), monthly mean (L1 mean), minimum mean (L1 mean) and actual minimum (L1 act min). Total rainfall mean was $415.5 \mathrm{~mm}$ for two years (Fig. 2) and the rest of the water requirement was provided by irrigation. The experiment was conducted as a factorial experiment in a randomized complete block design with four replications.

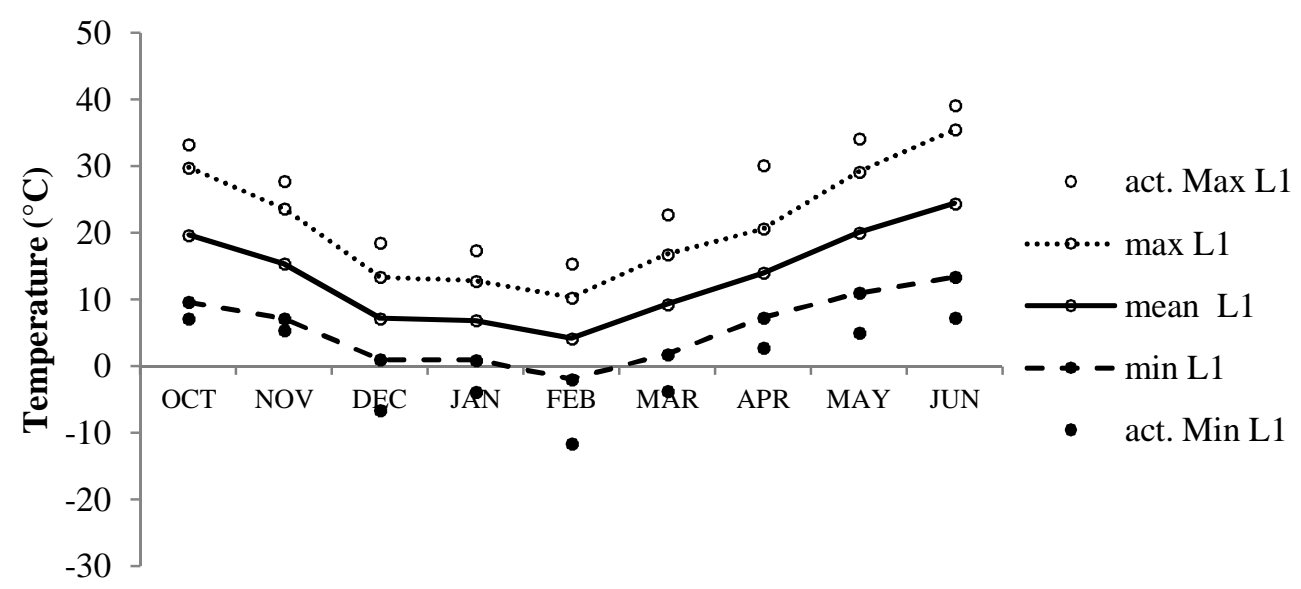

Fig. 1. Monthly temperature mean for two years in Khorramabad (L1).

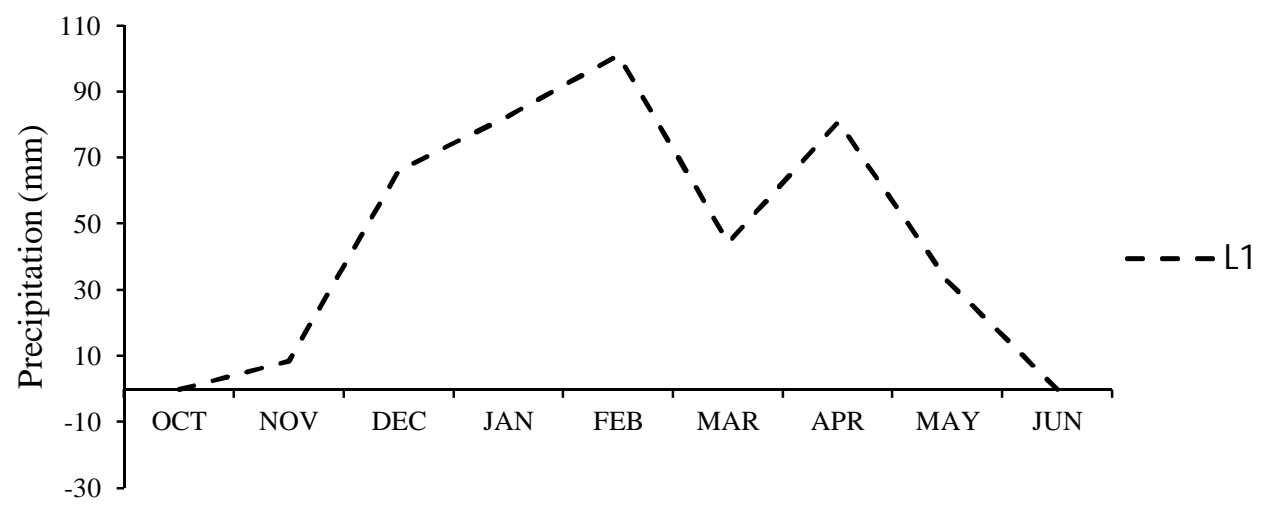

Fig. 2. Monthly mean precipitation for two years in Khorramabad (L1).

Biofertilizer factors included (application of Mycorrhiza, Azotobacter, Mycorrhiza and Azotobacter combination and non-application of biofertilizer) and cultivar factor (Gabriella, Neptune, Okapi and Expower). The cultivars used in this experiment were domesticated cultivars. Gabriella and Okapi are free pollinators and Neptune and Expower are hybrids. The soil was sampled prior to the experiment. Chemical and physical properties of soil of experimental field ( 0 - $30 \mathrm{~cm}$ depth) are presented in Tables 1 and 2. In the control treatment, only the fertilizer used 
from the source of ammonium phosphate was $100 \mathrm{~kg} / \mathrm{ha}$ and potassium sulfate $50 \mathrm{~kg} / \mathrm{ha}$ as soil test. Mycorrhizal inoculum was a Vesicular-arbuscular Mycorrhiza (VAM) fungus that was used as an active fungal organ (including spore, hyphae and root) and with Azotobacter. Seeds were inoculated with the above biological components before planting (Oct $3^{\text {rd }}, 2016$ and 2017). Cultivation was planar and each plot consisted of 6 planting lines $(6 \mathrm{~m}$ in length and $60 \mathrm{~cm}$ between lines). Each replication intervals were $2 \mathrm{~m}$ and plots were $1.5 \mathrm{~m}$ apart. Nitrogen fertilizer was applied from urea source in two stages one at rosette stage and another on tillering stage. Ammonium sulfate was applied at flowering stage at a rate of $50 \mathrm{~kg} \mathrm{~N} / \mathrm{ha}$. During harvesting time ten plants from each plot were harvested for morphological characters. Grain yield was also measured by harvesting four middle lines of each plot with a half-meter margin of the sides. Oil yield was obtained by multiplying the percentage of oil in grain yield. Biochemical parameters measured were chlorophyll by Arnon (1949), catalase and peroxidase by Bradford (1976) and proline and protein by Bates et al. (1973). Statistical analysis of data was performed using SAS 9.1 statistical software and comparisons were made by Duncan's multiple range tests at the 5\% level of probability.

Table 1. Chemical characteristics of soil.

\begin{tabular}{lcccccccccc}
\hline Location & $\begin{array}{c}\mathrm{K} \\
(\mathrm{mg} / \mathrm{kg})\end{array}$ & $\begin{array}{c}\mathrm{P} \\
(\mathrm{mg} / \mathrm{kg})\end{array}$ & $\begin{array}{c}\mathrm{OC} \\
(\%)\end{array}$ & $\begin{array}{c}\mathrm{Zn} \\
(\mathrm{mg} / \mathrm{kg})\end{array}$ & $\begin{array}{c}\mathrm{Fe} \\
(\mathrm{mg} / \mathrm{kg})\end{array}$ & $\begin{array}{c}\mathrm{Cu} \\
(\mathrm{mg} \mathrm{kg})\end{array}$ & $\begin{array}{c}\mathrm{OC} \\
(\%)\end{array}$ & $\begin{array}{c}\text { T.N.V } \\
(\%)\end{array}$ & $\begin{array}{c}\mathrm{pH} \\
\mathrm{EC} \times 10^{3} \\
(\mathrm{ds} / \mathrm{m})\end{array}$ \\
\hline Khorramabad & 248 & 3.5 & 0.95 & 0.45 & 18 & 2.0 & 0.95 & 37.1 & 7.3 & 0.51 \\
\hline
\end{tabular}

Table 2. Physical characteristics of soil.

\begin{tabular}{lcccccc}
\hline Location & $\begin{array}{c}\text { Sand } \\
(\%)\end{array}$ & $\begin{array}{c}\text { Silt } \\
(\%)\end{array}$ & $\begin{array}{c}\text { Clay } \\
(\%)\end{array}$ & $\begin{array}{c}\text { Soil } \\
\text { texture }\end{array}$ & $\begin{array}{c}\text { F.C } \\
(\%)\end{array}$ & $\begin{array}{c}\text { P.W.P } \\
(\%)\end{array}$ \\
\hline Khorramabad & 19 & 46 & 35 & Silty- clay & 28 & 13 \\
\hline
\end{tabular}

\section{Results and Discussion}

Canola proline content was significantly affected by biofertilizer, cultivar and the interaction of them (Fig. 3). Comparison of mean biofertilizer interactions in cultivar showed that the highest amount of shoot proline $(0.467 \mathrm{mg} / \mathrm{g}$ fresh weight) was obtained from Mycorrhiza application in Expower cultivar and the least was found from the control $(0.321 \mathrm{mg} / \mathrm{g}$ fresh weight $)$ in Okapi (Fig. 3). Rapeseed cultivars showed different levels of proline in response to different terms of biofertilizer application, but in Gabriella cultivar, application of all levels of biofertilizer reduced proline. Proline is an amino acid that is commonly increased in stress conditions and contributes to stress modulation by participating in osmotic regulation. In this study among the cultivars, Gabriella cultivar had least stress by using Mycorrhiza or Azotobacter and with no use of biofertilizer regulate drought stress by increasing proline. In one experiment it was found that among the plants inoculated with Mycorrhiza fungi, the highest proline content belonged to the symbiotic with $G$. mossaea which did not show any significant difference with other treatments (Aslani et al. 2009) who also reported that proline content in coriander was not affected by mycorrhizal fungi under water stress conditions. Studies showed that under coexistence with mycorrhizal fungi, proline content is under reduced stress conditions (Muller and Hofner 1991) or increases (Wu and Xia 2006). 


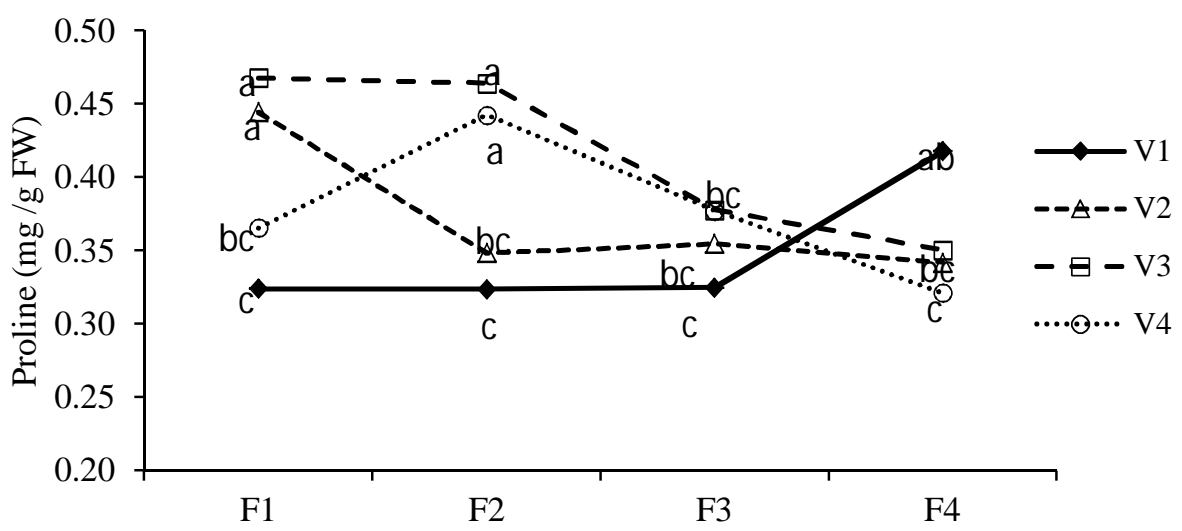

Fig. 3. Mean comparison of interaction effect of cultivar on biofertilizer on shoot proline. $\mathrm{F} 1=$ Mycorrhiza, $\mathrm{F} 2=$ Azotobacter, F3 = Mycorrhiza + Azotobacter, F4 = Control, V1 = Gabriella, V2 $=$ Neptune, V3 $=$ Expower, V4 = Okapi. Same letter are not different at 0.05 confidence level.

Total protein content of canola was found significant with the effect of cultivar and the interaction of biofertilizer and cultivar. Interaction of biofertilizer in cultivar showed that maximum amount of shoot protein $(0.51 \mathrm{mg} / \mathrm{g}$ fresh weight) was obtained from Azotobacter application alone and application of Azotobacter with Mycorrhiza in Neptune cultivar and the lowest was obtained from non-application of biofertilizer in Gabriella $(0.31 \mathrm{mg} / \mathrm{g}$ fresh weight $)$ (Fig. 4). Unlike proline amino acid and unstructured soluble sugars, shoot protein is generally reduced under stress conditions. It converts into smaller molecules such as proline amino acid and modulates stress by participating in osmotic regulation. Mycorrhiza and Azotobacter combination

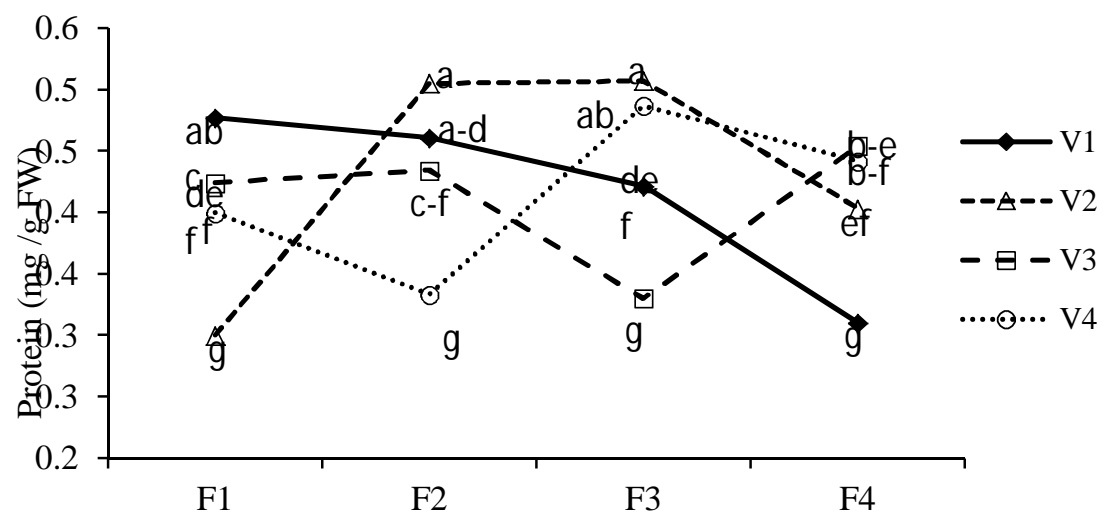

Fig.4.Interaction effect of cultivar on biofertilizer on total shoot protein.

application produced the highest amount of total shoot protein and non-application of biofertilizer accounted for the least, which could be attributed to the increased nitrogen uptake caused by the use of biofertilizer. Soluble proteins and total nitrogen content in mycorrhizal inoculated maize plants have been reported higher than non-mycorrhizal plants (Abo-Ghalia and Khalafallah 2008). According to Heshmati et al. (2016) inoculation of biofertilizer with spring safflower increased the activity of catalase and the amount of soluble leaf proteins in stress conditions at vegetative and reproductive stages. These reactions can reduce the adverse effects of stress. 
Canola peroxidase levels were significantly affected by biofertilizer and cultivar and the interaction of biofertilizer and cultivar. Interaction of biofertilizer in cultivar showed that the utmost amount of shoot peroxidase $(0.796 \mathrm{mg} / \mathrm{g}$ fresh weight $)$ was achieved from mycorrhiza application in Neptune cultivar and the lowest was from Azotobacter application in Gabriella (0.42 $\mathrm{mg} / \mathrm{g}$ fresh weight) (Fig. 5). Peroxidase is a shoot antioxidant that usually grows under stress conditions and suppresses free radicals and modifies stress. The combination of Mycorrhiza and Azotobacter produced the lowest levels of shoot peroxidase. Increased activity of antioxidant enzymes in spring safflower due to high consumption of phosphorus fertilizer has been reported by Heshmati et al. (2016). A combination of antioxidant enzymes such as superoxide dismutase (SOD), glutamine reductase, catalase, and peroxidase are important factors in tolerating environmental stresses in different plants (Jithesh et al. 2006). Increased plant enzymatic activity (polyphenol oxidase and peroxidase) is associated with increased total phenol content in fungal inoculated specimens (Charitha and Reddy 2002).

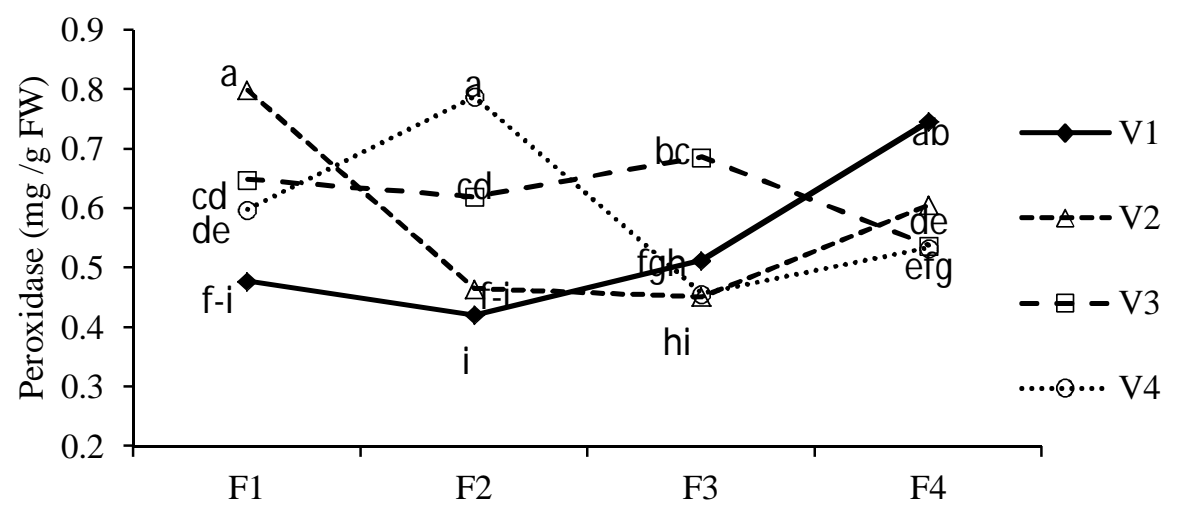

Fig. 5. Interaction effect of cultivar on biofertilizer on shoot peroxidase.

Shoots Catalase level was affected significantly by biofertilizer and cultivar and the interaction of biofertilizer and cultivar. Interaction of biofertilizer in cultivar showed that the highest amount of shoot catalase $(0.606 \mathrm{mg} / \mathrm{g}$ fresh weight) was obtained from non-application of biofertilizer with cultivar Gabriella and minimum was obtained by the combined application of biofertilizer in the Okapi cultivar (0.4 mg/g fresh weight) (Fig. 6). The combination of Mycorrhiza and Azotobacter produced the lowest amount of catalase and non-application of biofertilizer produced the highest, which could be attributed to the improvement of growth conditions due to the use of biofertilizer. Increased levels of carbon and enzymes of urase, phosphatase and catalase in the soil caused by the combination of organic and biological fertilizer increased the growth of pumpkin and biological properties of the soil (Cao et al. 2010). A combination of antioxidant enzymes such as superoxide dismutase (SOD), glutamine reductase, catalase, and peroxidase are important factors in tolerating environmental stresses in different plants (Jithesh et al. 2006).

Chlorophyll $\mathrm{a}$ and $\mathrm{b}$ were significantly affected by biofertilizer and cultivar and the interaction of biofertilizer and cultivar (Figs 7 and 8). Interaction of biofertilizer in cultivar showed that the highest amount of chlorophyll a $(1.06 \mathrm{mg} / \mathrm{g}$ fresh weight $)$ was obtained from combined application of Mycorrhiza and Azotobacter in Neptune and chlorophyll b $(0.308 \mathrm{mg} / \mathrm{g}$ fresh weight) was obtained from non-application of Mycorrhiza and Azotobacter (control) in Expower. The least was obtained by the combined application of Mycorrhiza and Azotobacter in 


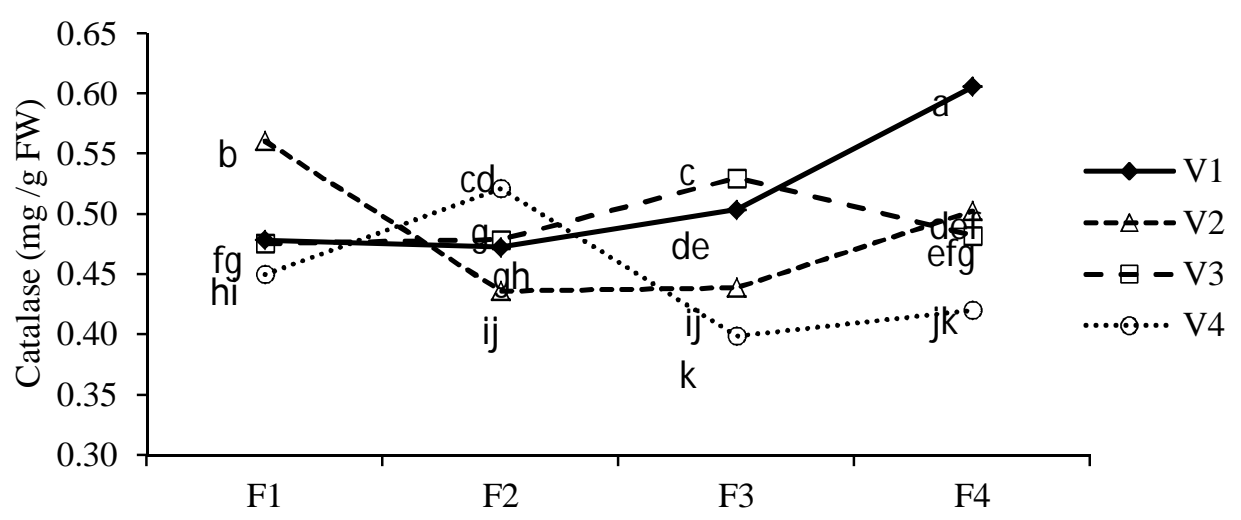

Fig. 6. Interaction effect of cultivar on biofertilizer on shoot catalase.

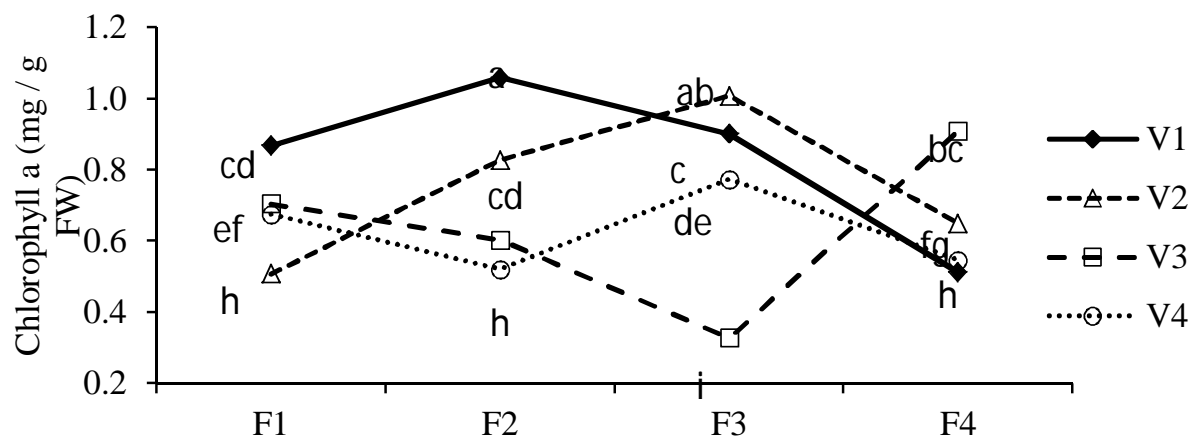

Fig. 7. Interaction effect of cultivar on biofertilizer on Chlorophyll a.

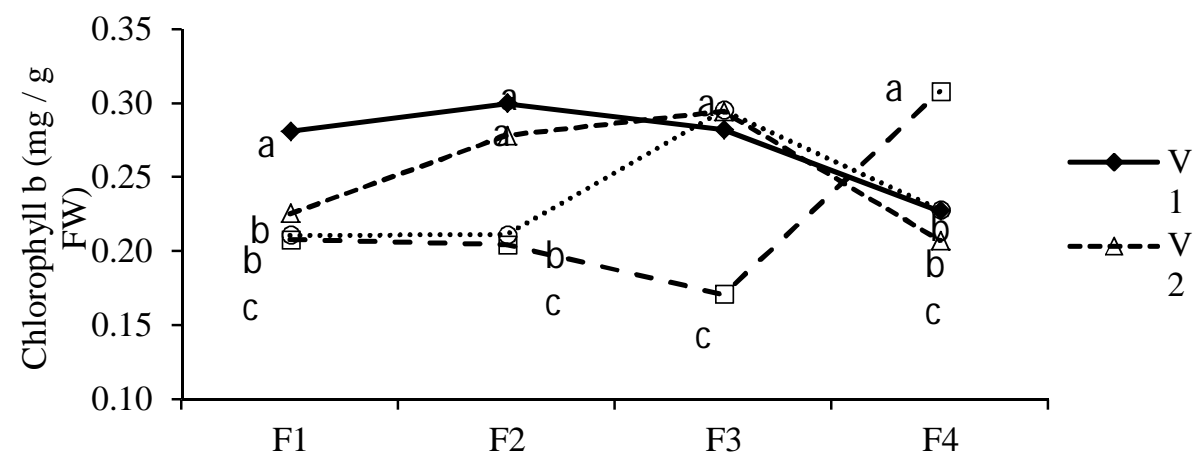

Fig. 8. Interaction effect of cultivar on biofertilizer on Chlorophyll b.

Expower (0.327 and $0.171 \mathrm{mg} / \mathrm{g}$ fresh weight). Chlorophyll $\mathrm{a}$ and $\mathrm{b}$ is the most important photosynthetic pigment directly involved in photosynthesis. The combined application of Mycorrhiza and Azotobacter produced the highest amount of chlorophyll a and b in shoots and non-application of biofertilizer was the least which might be due to the improvement of growth conditions by the use of biofertilizer. Significant increases in plant leaf chlorophyll content in 
response to inoculation with mycorrhizal fungi have been reported by Demir (2004). Sharifi et al. (2011) also found a significant increase in chlorophyll $\mathrm{a}$ and $\mathrm{b}$ content in green and purple basil leaves inoculated with mycorrhizal fungi. Valentin et al. (2006) found that photosynthetic rate of maize leaf significantly increased in Mycorrhiza inoculation and inoculation with Azotobacter compared to control treatment. Inoculation of corn seeds with Mycorrhiza biofertilizers significantly increased leaf chlorophyll in the plant, which ultimately increased plant photosynthesis and seed yield, indicating the importance of phosphorus in chlorophyll synthesis and thus plant photosynthesis rate. Microorganisms, due to their high impact on soil phosphorus uptake, make the inoculated plants to have a higher yield (Eteshami 2008).

Grain yield was significantly affected by cultivar and biofertilizer and the interaction of biofertilizer and cultivar. Comparison of mean biofertilizer in cultivar showed that maximum grain yield of Gabriella with combined application of Mycorrhiza and Azotobacter application with average of $4919 \mathrm{~kg} / \mathrm{ha}$. The minimum grain yield was obtained from Expower and non-application of biofertilizer with an average of $3350 \mathrm{~kg} / \mathrm{ha}$ (Fig. 9). Aslani et al. (2009) studied that symbiosis with mycorrhizal fungi increased plant dry matter yield under both stress and non-stress conditions. This increase in yield has been attributed to improved vegetative growth of the plant as

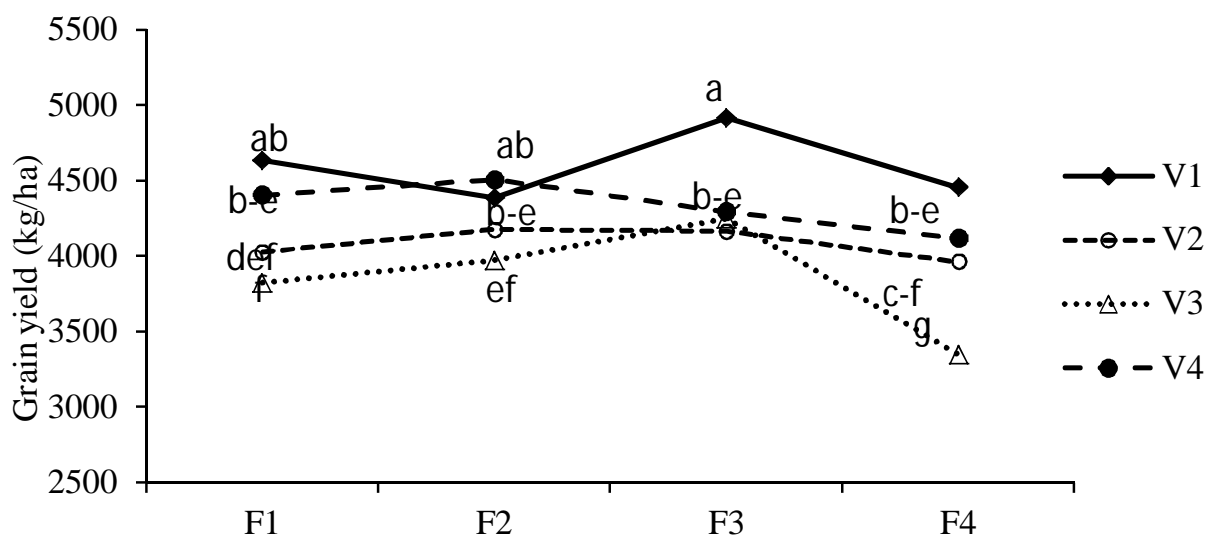

Fig. 9. Interaction effect of cultivar on biofertilizer on grain yield.

a result of improved water relations and plant nutrition, especially phosphorus. Positive and direct effect has also been reported of azotobacter bacterial application and azospirillum biofertilizers on rapeseed yield (Hasanzadeh GhurtTapeh and Javadi 2015, Yasari et al. 2009). Increased yields from Azotobacter inoculation caused by immobilization of ammonium nitrate, phosphate, potassium, and iron, improved water distribution in the plant, and increased nitrate reductase activity (Kader et al. 2002). The reason for the increased yield due to the use of biofertilizers is their synergistic effects (Omidi et al. 2014). Oil yield was significantly affected by simple effects of cultivar and biofertilizer. Among the cultivars, the highest oil yield belonged to Gabriella (1927 $\mathrm{kg} / \mathrm{ha}$ ) and the lowest was to Okapi (1584 kg/ha). Among the biofertilizer levels, the highest oil yield was obtained with the combined use of biofertilizers $(1819 \mathrm{~kg} / \mathrm{ha})$ and the lowest was with the non-biofertilizer application (1639 kg/ha) (Fig. 10). The oil yield changes affected by the experimental factors in this study are mostly similar to the grain yield, which is consistent with the finding of Yasari et al. (2009), Hasanzadeh Ghorttapeh and Javadi (2015). Omidi et al. (2014) 


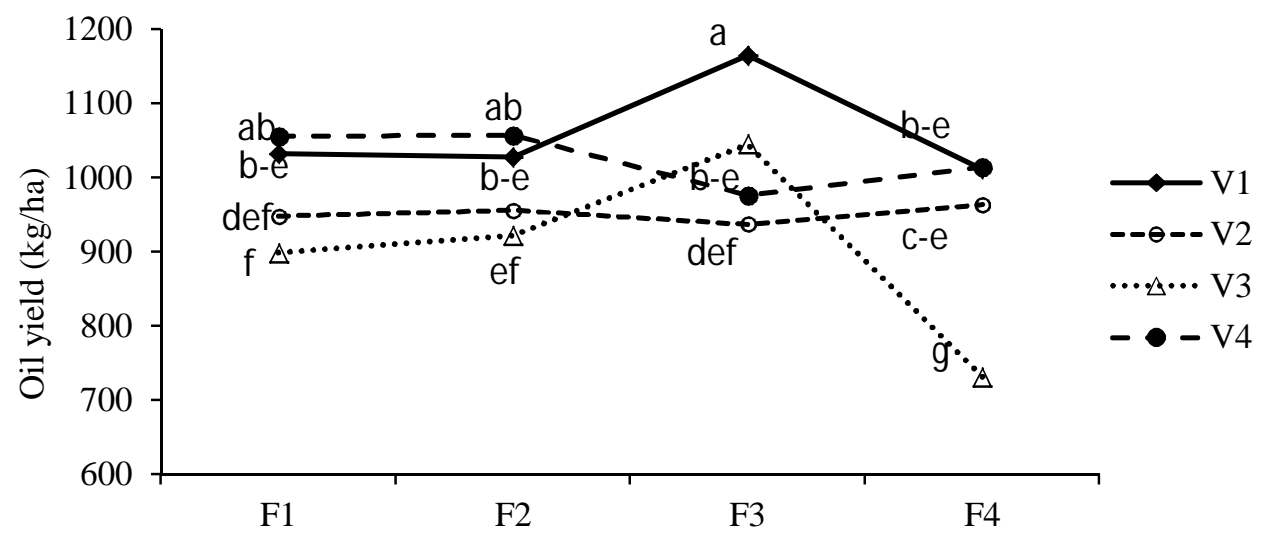

Fig. 10. Interaction effect of cultivar on biofertilizer on grain oil.

reported that synergistic effect between Mycorrhiza and Azotobacter increases oil yield in safflower. The response of cultivars to different levels of biofertilizers was different but Gabriella cultivar tried to modify the drought stresses of the plant by increasing proline. Application of biofertilizers increased plant tolerance to stress because it increased photosynthetic pigments and decreased proline.

\section{References}

Abo-Ghalia H and Khalafallah A 2008. Responses of Wheat Plants Associated with Arbuscular mycorrhizal Fungi to Short-term Water Stress Followed by Recovery at Three Growth Stages. J. Appl. Sci. Res. 4(5): 570-580.

Ahmad A, Khan I, Anjum NA, Abrol YP and M Iqbal 2005. Role of sulphate transporter systems in sulphur efficiency of mustard genotypes. J. Plant Sci. 169: 842-846.

Arnon, D.I. 1949. Copper enzymes in isolated chloroplasts. Polyphenoloxidase in Beta vulgaris. Plant Phisiol. 24: 1-15.

Aslani Z, Hasani A, Rasuli M, Sedghiani F, Sefidkan MandGheibi A 2009. The effect of symbiosis with Mycorrhiza on some physiological parameters of basil under drought stress conditions. Iranian J. Med. Aromat. Plants Res. 27(3): 471-486.

Barea JM, Aguilar CA and Azcon R 1997. Interactions between mycorrhizal fungi and rhizosphere microorganisms within the context of sustainable V.K. (Ed.). Multitrophic interactions in terrestrial systems. Cambridge; Blackwell Sci. pp. 65-77.

Bates LS, Waldren RP and Teare ID 1973. Rapid determination of free proline for water-stress studies. Plant and Soil 39: 205-207.

Bradford M 1976. A rapid and sensitive method for the quantification of microgram quantities inutilizing the rinciple of protein dye binding. Analyt. Biochem. 72: 254-284.

Cao D, Liang-Gang Z, Xiao JZ and Qian ZY 2010. Effects of biofertilizer on organically cultured cucumber growth and soil biological characteristics. Chinese J. Appl. Ecol. 21(10): 2587-2592.

Charitha DM and Reddy MN 2002. Phenolic acid metabolism of groundnut (Arachis hypogaea L.) plants inoculated with VAM fungus and Rhizobium. Plant Growth Regulation 37: 151-156.

Demir S 2004. Influence of arbuscular mycorrhiza on some physiological, growth parameters of pepper. Turk. J. Biol. 28: 85-90.

Ehteshami SMR 2008. Effect of phosphate biofertilizers on quantitative and qualitative indices of grain corn (Zea mays L.) under water deficit stress. Ph.D. Thesis, Tarbiat Modarres University, Tehran, Iran. page 221. 
Hasanzadeh Ghurttapeh A and Javadi H 2015. Effects of nitrogen fertilizer application and inoculation with biological fertilizers (Azospirillum and Azotobacter) on yield, yield components and spring rapeseed oil in West Azerbaijan. J. Crop Production and Processing 5(18): 49-39.

Heshmati S, Amini Dehghi M and Fathi Amirkhiz K 2016. Effect of phosphorus and chemical fertilizer on antioxidant enzymes activity and some biochemical traits of spring safflower (Carthamus) under water deficit stress. J. Crop Produc. Proce. 6 (19): 213-203.

Jithesh MN, Prashanth SR, Sivaprakash KR and Parida AK 2006. Antioxidative response mechanisms in halophytes: their role in stress defense. J. Genet. 85: 237-254.

Kader A 2002. Post-harvest technology of horticultural crops. University of California, 2002: Publication 3311. Davis, CA, USA.

Muller I and Höfner W 1991. Influence of the VA-mycorrhiza on p uptake and recovery potential of corn (Zea mays L.) under water stress conditions. Z. Pflanzenernahr. Bodenkd. 154: 321-323.

Nematollahi Z and Saeidi G 2011. Study of drought tolerance in some genotypes of flax (Linum usitatissimum L.). J. Water Res. Agricul. 25: 57-65. (In Farsi).

Omidi K. Hooshyar M, Jessulat M, Samanfar B, Sanders M, Burnside D, Pitre S, Andrew Schoenrock, Xu J, Babu M and Golshani A 2014. Phosphatase complex Pph3/Psy2 is involved in regulation of efficient non-homologous end-joining pathway in the yeast Saccharomyces cerevisiae. PLoS One 9(1): e87248.

Seyed Sharifi R 2007. Industrial Plants. Mohaghegh Ardabili Press. Ardabil. (In Farsi). page 193.

Sharifi M, Sadat Mohtashmian M, Riahi h, Aghaee A and Alavi SM 2011. The effect of Glomus etunicatum endomycorrhizal fungi on some morphological and physiological indicators of basil. J. of Medicinal Plants. Tenth year. Second period. pp. 85-94.

Smirnoff N 1993. The role of active oxygen in the response of plants to water deficit and desiccation. New phytologist 125: 27-58.

Valentine AJ, Mortimer PE, Lintnaar A and Borga R 2006. Drought respinses of arbuscular mycorrhiza on grapevines. Symbiosis 41: 127-133.

Wu Q Sh and Xia RX 2006. Effects of arbuscular mycorrhizal fungi on leaf solutes and root absorption areas of trifoliate orange seedlings under water stress conditions. Front. Forest. China. 3: 312-317.

Yasari E, Azadgoleh MR, Mozafari S and Alashti M 2009. Enhancement of growth and nutrient uptake of rapeseed (Brassica napus L.) by applying mineral nutrients and biofertilizers. Pakistan J. Bio. Sci. 12(2): 127-33.

Zhou WJ 1994. Oilseed cultivation. In: Ding YS (Editor). Cultivation of Crops. Shanghai Sci. and Tech. Press. Shanghai. 357-380.

(Manuscript received on 30 May, 2020; revised on 10 November, 2020) 